\title{
Musgrave, Samuelson, and the crystallization of the standard rationale for public goods
}

\author{
Maxime Desmarais-Tremblay ${ }^{1}$
}

\begin{abstract}
This paper provides a narrative of the emergence of the standard textbook definition of public goods. It focuses on Richard A. Musgrave's contribution in defining public goods as non-rival and non-excludable-from 1937 to 1973. Although Samuelson's mathematical definition is generally used in models of public goods, the qualitative understanding of the specificity of pure public goods owes a lot to Musgrave. I argue that the evolution of Musgrave's writings on public goods reflects his intention to justify his view of the role of the state in providing goods and services to the citizens with an argument that would be convincing to the community of American economists in the middle of the twentieth century. Musgrave's definition highlights his life-long concern for a comprehensive, realistic and useful normative theory of the public sector.
\end{abstract}

Keywords: Richard A. Musgrave; Paul A. Samuelson; social goods; public goods; non-rivalry; nonexclusion; free riding.

JEL Codes: H41, B29, B31

1 maxime.desmarais-tremblay@unil.ch. Centre Walras-Pareto, Université de Lausanne, IEPHI Geopolis, 1015 Lausanne, Switzerland and Centre d'Économie de la Sorbonne, Université Paris I Panthéon-Sorbonne. An earlier version of this paper (Desmarais-Tremblay 2013) was presented at the $17^{\text {th }}$ ESHET annual Conference in Kingston (May 2013) and at the $14^{\text {th }}$ Summer Institute for the History of Economic Thought at the University of Richmond (June 2013). More recent versions were presented at the HPPE seminar at LSE (January 2015), at the Albert O. Hirschman (AOH) Doctoral Seminar at the Centre d'économie de la Sorbonne (CES, University Paris I) (February 2015), at the $9^{\text {th }}$ History of Recent Economics Conference in Cergy-Pontoise (May 2015), and at the $71^{\text {st }}$ Annual Congress of the International Institute of Public Finance in Dublin (August 2015). I am grateful to the participants of these seminars and workshops for their comments. I am also grateful to Richard Sturn, Jérôme Lallement, Roberto Baranzini, Pascal Bridel, Annie L. Cot, Jean-Sébastien Lenfant, Yann Giraud, Harro Maas, Roger Backhouse, Pedro Duarte, Benjamin M. Marx, and others for their feedback. I have benefited from unpublished material from the Alan T. Peacock Papers at the University of St Andrews and from the Samuelson Papers at the David M. Rubenstein Rare Book and Manuscript Library at Duke University. I am indebted to Anabel Farrell, Daniel Hammond and David Pavelich for material from these collections. I am also thankful for the generous support of the Friends of the Princeton University Library for conducting research in the Richard A. Musgrave Papers. I am obliged to the staff of the Mudd Library at Princeton, especially to Daniel J. Linke. Finally, I express my gratitude to the editor of this journal and to two anonymous referees. Their suggestions have greatly improved the paper. Any remaining errors are mine own. 
Imagining counterfactual history, surely it would have been better if there had been a 1954 item by Musgrave and Samuelson that led to a post-1970 Nobel Prize in economics. Indeed, many discerning academics believe that Stockholm erred in not honoring the author of Musgrave's Theory of Public Finance. (Samuelson 2008)

This paper is on the history of the concept of Public Goods, which came to maturity in the New American public finance, roughly from the 1930s to the end of the 1960s. It focuses on Richard A. Musgrave's contribution, which has been overshadowed by Samuelson's (1954, 1955) brilliant formal exposition. The popular misconception is well represented in a recent entry on free riding written by Russell Hardin in the Stanford Encyclopedia of Philosophy:

Olson based his analysis on Paul Samuelson's theory of public goods. Samuelson (1954) noted that some goods, once they are made available to one person, can be consumed by others at no additional marginal cost; this condition is commonly called jointness of supply or nonrivalness of consumption. [...] There is a second feature of Samuelson's public goods that would make them problematic in practice: the impossibility of exclusion. (Hardin 2003, 8-9)

As I will argue, Musgrave's role is decisive, especially on the standard textbook definition that Hardin referred to. Pure public goods are commonly defined in textbooks as being neither rival nor excludable. Musgrave (1969a) was the first to use this two-criteria definition.

This definition is used in public economics textbooks (Cornes and Sandler 1996; Hindriks and Myles 2006; Gruber 2011), as well as in microeconomics textbooks (Varian 1992; Nicholson and Snyder 2011). None of the aforementioned authoritative texts refer to Musgrave on the topic of public goods, but they all refer to Samuelson. Furthermore, most of them make use of a $2 \times 2$ table in order to classify four different families of goods according to the possibility of excluding consumers from their benefits, and whether they are intrinsically rival (see Table 1). This pedagogical device was first conceived by 
Musgrave and Musgrave (1973), although no reference to its origin is to be found in any textbook. ${ }^{2}$

Although a few scholars-those who knew Musgrave personally, or who studied his work closely-recognized his contribution, no systematic and retrospective analysis of Musgrave's role in defining public goods has been made. ${ }^{3}$ Motivated by Samuelson's remark, the goal of this paper is to fill the gap described above in the history of the theory of public goods, by appraising Richard A. Musgrave's contribution. I argue that the concept of public goods illustrates Musgrave's intention to justify his view of the role of the state in providing goods and services to the citizens with an argument that would be acceptable to the community of American economists in the middle of the twentieth century. Samuelson played a decisive role in the evolution of the conceptualization of public expenditures, yet Musgrave's two-criteria definition reflects his life-long concern for a comprehensive, realistic, and useful normative theory of the public sector. Moreover, the evolution of Musgrave's writings on public goods exemplifies the refining of a theoretical question through exchanges with colleagues, in particular Samuelson.

\section{Musgrave before Samuelson}

\subsection{Musgrave's early synthesis}

Born in Königstein in 1910 to a family of German intellectuals, Musgrave studied at the University of Munich and at the University of Heidelberg, where he obtained his Diplom

\footnotetext{
2 On economists' strategic moves for recognition and the historiographic challenges of attributing credit to scientific discoveries in postwar economics, see Düppe and Weintraub (2014, pp. xvi; 233). To the extent that the two-criteria definition given by Musgrave is used mostly in lower-level textbook literature, the lack of credit is perhaps less surprising (see Medema 2012).

${ }^{3}$ See for instance, Atkinson (1987), Seidl (1988), Pickhardt (2006), Oates (2007).
} 
Volkswirt degree in 1933 (Musgrave 1986, 1997; Sinn 2009). Through the teaching of Adolf Weber, Otto von Zwiedineck, Alfred Weber, Jakob Marschak, and Otto Pfleiderer, he became acquainted with European scholarship on public finance, economics, law, and sociology. He then moved to the US in 1933 on a one-year scholarship to study at the University of Rochester, but, with the turn of events in Germany, decided to stay. As a result, he became part of a generation of German-speaking scholars who had emigrated to the United States and contributed to the internationalization of economics in an American synthesis (Craver and Leijonhufvud 1987; Hagemann 2011).

Musgrave's "comparative advantage" lay in his acquaintance with continental literature on public finance (Musgrave 1992, 1997). ${ }^{4}$ Musgrave's unpublished dissertation on The Theory of Public Finance and the Concept of Burden of Taxation (1937) drew heavily on this literature. He tried to synthesize different theoretical works on public expenditures and on taxation from the end of the nineteenth century to the first part of the twentieth. From a traditionally narrow focus on "the burden of taxation", Musgrave enlarges the research agenda of Public finance to the net effect of the government revenues and expenditures processes. He thus clearly sets his research within the framework of welfare economics, but with consideration of the benefits of the state's economic activities. This reorientation is justified by the increasing importance of public expenditures (Musgrave 1937, 20-21). In the midst of the New Deal, government spending had become a burning

${ }^{4}$ When Musgrave arrived in the United States in 1933, public finance was a subfield that had coalesced around progressive economists at Wisconsin and at Columbia. Yet the influence of American progressives was fading in the early 1930s, as Pigou (1928) became the leading text (Johnson 2014, 2015a). 
question as "economics had moved to the forefront of politics" (Musgrave 1997, 65) (see also Johnson 2015c).

Regarding the question of the assessment of the benefits of the services provided by the Public Economy, Musgrave rejects the Italian subjectivist assumption: "the basic assumption of individual evaluation of collective wants, considering the latter as homogeneous with individual wants proper, appears unrealistic" (Musgrave 1937, 38). ${ }^{5}$ Yet Musgrave also rejects the opposite perspective which assumes that the state is the subject of organic wants (ibid., 49). Furthermore, on the subject of the science of public finance, he remarks: "political decisions are formulated as being so complex that no attempt to rationalize the latter in terms of individual evaluation can be undertaken without extensive sociological analysis of the prevailing institutional set-up" (ibid., 40). ${ }^{6}$ He considers a National Economy as a system that comprises two legitimate spheres-Market Economy and Public Economy-in an interrelationship, and both drawing from the same pool of resources. The Public Economy seen as planned household has its own logic. Carving a middle-of-the-road position typical of the 1930s, Musgrave did not see the market as the baseline for all economic life, and neither was it for the study of public finance. As Musgrave $(1937,73)$ puts it: "The interpretation of Public Economy as planned or

\footnotetext{
${ }^{5}$ In the first chapter of his dissertation, Musgrave reviews the three main traditions in public finance on their view of the public economy: the classical British tradition, the German triad (L. von Stein, A. E. Schäffle, and Adolf Wagner), and what he labels the Exchange economy perspective (E. Sax, K. Wicksell, and E. Lindahl). Through the latter German-writing authors, he also discusses their Italian predecessors, namely A. Di Viti de Marco and Ugo Mazzola.

${ }^{6}$ Both subjectivist assumptions were important for Italian scholars like De Viti de Marco (1934) and Mazzola (1890). They adapted the analytical apparatus of the marginalist theory of value to public expenditures The state is thus conceived as an aggregation of individuals who (voluntarily) pay taxes in exchange of services. Moreover, they assumed that individuals are able to directly feel and assess the benefits of the public goods.
} 
household economy is in closer agreement with actual institutions than the other explanation in terms of market exchange; consequently the former approach offers a better tool for the comparison of actual conditions with the theoretical model."

Just as the economist usually assumes that the consumer has given preferences, Musgrave assumes that the subject of public finance (the budget planner) works on the basis of a given schedule of social wants. In the 1950s, following Samuelson's (1947) work inspired by Bergson (1938), Musgrave substituted the concept of the social welfare function for his earlier expression of a schedule of social wants. This assumption partly explains why, in his dissertation, Musgrave is not yet trying to identify specific criteria for public expenditures. In a Wagnerian fashion, he merely indicates that the actual collective wants and socially interpreted individual wants satisfied by publicly provided goods depend on historical, political and social factors. In the end, Musgrave wants to assess the welfare 'net effect' of the public economy, but he acknowledges that his accounting procedure runs into difficulties in assessing the benefits of public expenditures (Musgrave 1937, 121). Like many before him, Musgrave argued that some public expenditures satisfy collective wants that cannot be easily traced to individual needs due to their indivisible nature. ${ }^{7}$ Musgrave calls them 'social wants proper' (ibid., 120, 335). ${ }^{8}$ This issue is neither

\footnotetext{
7 This is distinguished from the other problem of indivisibility due to the "bulky" nature of some goods (ibid., 395). Musgrave does not really discuss this case, but one can understand something like a problem of 'joint supply', or 'indivisibility' on the supply side, which has to be distinguished from the problem of indivisibility on the consumption side. Similar ideas are stated by Wagner (1892, 275 ff.) and Smith (1776 V.i, 723).

8 The idiom is likely adapted from Sax's (1924) expression of "collective wants proper" (eigentlichen Kollektivbedürfnisse). For earlier statements of the idea of indivisibility, see De Viti de Marco (1934, 80), Sax (1924), Wagner (1892, 275, 419); Leroy-Beaulieu (1906, 175) and Seligman (1908). All of
} 
the central nor the most original aspect of Musgrave's dissertation, however, it is very important for the discussions that will follow on the specificity of public goods. Musgrave assumes there exists individual wants, and collective wants proper. Most of the first ones are satisfied within the market economy, but the public economy may satisfy both collective wants proper and "socially interpreted individual wants" (ibid., 335). This conceptualization clearly anticipates the function of the Allocation branch in the Theory of Public Finance (1959) which is to provide goods to satisfy public wants of two kinds: social wants and merit wants. ${ }^{9}$ By highlighting its productive capacity, its role in providing necessity goods, and its lawful ability to interfere with individual wants satisfaction, a relatively positive view of the state emerges from Musgrave's early work.

\subsection{Free riding and non-exclusion}

In 1939, two years after defending his PhD thesis at Harvard, Musgrave's first paper was published in the Quarterly Journal of Economics while he was serving as instructor in the Harvard's economics department. Based on his dissertation, the paper is a reconstruction of the voluntary exchange theory of public economy as can be found in Sax, De Viti De Marco, Wicksell, and, in a more mature form, in Lindahl. From their perspective, "taxes accordingly appear as voluntary payments rendered by the individual in exchange for services supplied by public economy, and in accordance with his evaluation of those services" (Musgrave 1939, 214). The young Musgrave, put forward many arguments

these works are referred to by Musgrave (1937). Colm $(1934,325)$ also makes a similar observation. See also Sturn (2006).

${ }^{9}$ Merit wants are human needs of such importance for the community that their satisfaction cannot be left to the market, even if the goods which satisfy them do not suffer from non-exclusion or nonrivalry problem. The first examples of merit goods given by Musgrave are transfers in kind like housing for the poor, school lunches and healthcare services. See, Desmarais-Tremblay (Forthcoming). 
against the voluntary approach—but his main contention is the "highly unrealistic" nature of a model that relies on the hypothesis of voluntary exchange. He writes: "The very fact that such enforcement appears universally necessary indicates the absence of a general willingness to comply with the obligation to contribute" (ibid., 219). Musgrave comes up with a behavioral rationale to explain this "fact". What will eventually become the standard argument for public good provision is found in a long footnote:

We note the theoretical difficulty which arises for the voluntary exchange theory in the event that some of the members of the community should attempt to benefit from public services without in turn being eager to contribute their share. While recognized as constituting a 'pathological group' (De Marco, [1934], p. 114) and a 'problem' (Benham [1934], p. 454), they are ruled out by the assumption of purely voluntary action. Assuming, however, for the sake of argument that all people act in the prescribed 'pathological' manner, the following problem arises: if the total cost of public services is covered by a large number of contributors, a reduction in the contribution of any one contributor will fail to affect notably the total supply of public services - either from the point of view of this contributor or in the eyes of other contributors who join in the consumption of the same indivisible services. Hence the reduction will result in a gain for the contributor in question without leading to reprisals. If all contributors should accordingly decide to reduce their contributions, the volume of public services will tend to shrink, and an unstable situation will result. (Musgrave 1939, 219-20, n.5)

One finds here the first clear exposition in English of what would later be called the free riding hypothesis. ${ }^{10}$ It derives from the situation where a large number of individuals contribute to a collective good or service. Because of this large number of contributors and the fact that they all benefit collectively from the service, one individual could reduce his contribution (if he were not forced to pay for it) without the others noticing. This individual would then be free riding—-benefiting from the service without actually paying for it. Yet, if

\footnotetext{
${ }^{10}$ For forerunners of this reasoning, see Sax $(1924,212)$, De Viti de Marco (1934, 113-14), Benham (1934, 452-54), and Wicksell $(1896,81-82)$. The more general idea that the state is justified to intervene to prevent non-cooperative behavior in certain contexts is already found, for instance, in Hume, Smith and Sidgwick. See Medema (2009).
} 
many act like him, the aggregate level of contribution would fall and the service could not be properly funded. Musgrave's argument achieved what was probably an unintended success. At the very least, Musgrave did not need this argument to convince himself that the state had a positive role to play in the welfare of the citizens in a democratic society. This was already assumed in the approach to public economy he adopted in his dissertation. It is also a consequence of the progressive narrative of Wagner's Law endorsed by Musgrave throughout his life. ${ }^{11}$ Yet, this argument convinced some economists that public provision of specific goods was required (about which more below), in part because it relied on an assumption of selfish rationality which later became common place in the middle of the twentieth century. What eventually became the rational behavioral response could still be considered a pathological case in the 1930s (Pickhardt 2005; Tuck 2008; Fontaine 2014).

This convincing argument had the paradoxical effect of narrowing the scope of collective wants to those which are satisfied by goods that can provoke free riding behavior if left to voluntary provision. When compared to the broad range of human motivations contemplated by Wagner (1892) and Sax (1924), among others, the straw man that Musgrave sets up in order to attack voluntary provision appears thin. ${ }^{12}$ Following Wicksell, but contrary to De Viti de Marco and Benham, Musgrave assumes for the sake of argument that everyone behaves as such. Still, it is only for the argument, since Musgrave did not

11 Wagner $(1883 ; 1892,379)$ perceived that there was something constitutive of economic progress that would lead to an increasing role for the state. He observed a relative (and absolute) growth in public expenditures in many Western European countries and argued that it was the result of pressures for social progress.

12 This had the consequence of leaving out of the public good category many government interventions that were not justifiable in a selfish way. I argued elsewhere that the concept of merit goods was coined by Musgrave to capture those goods and services (Desmarais-Tremblay 2015). 
really believe that individuals always behave in a selfish way: "The hypothesis that the motive of action is purely egoistic is as unrealistic as the other assumption that it is purely altruistic: In reality political action is motivated by both forces" (Musgrave 1937, 333).

Buchanan (1964) was the first to use the expression of free rider in public finance. He later theorized it as a specific case-alongside perfect competition—of a more general "large number dilemma." Buchanan (1964) does not refer to Musgrave (1939), but he probably had read the paper, since he refers to it in "Knut Wicksell on Marginal Cost Pricing" (1951). It is also cited by Baumol (1952) and Downs (1957). Moreover, Peacock (1954) uses the free riding argument as a criticism of Lindahl's model on the same page in which he cites Musgrave (1939). The generalization of the free riding argument to all collective action was made by Olson (1965) (Dougherty 2003). At the beginning of his treatise, he makes explicit reference to Musgrave on non-exclusion: "The second point is that once the relevant group has been defined, the definition used here, like Musgrave's, distinguishes collective good in terms of infeasibility of excluding potential consumers of the good" (p. 14). Although this idea could have come to him from Musgrave's Theory (1959), he also makes a reference to the 1939 paper.

By making a caricature of its essential features, Musgrave successfully attacked the voluntary exchange tradition as a positive model (Fossati 2003). Yet, it survived as a normative horizon - that of free individual exchange-in Buchanan's research program on public goods and more generally on constitutional political economy (Johnson 2015b).

At the end of his first paper, Musgrave alluded to a "planning approach" in place of the voluntary exchange model. Based on his dissertation, this approach will be criticized 
the next year by Neal (1940). The latter contended that the formation of a social preference scale in which an individual could compare the benefits he gets from the protection of an additional destroyer to eating another apple was not feasible. Concluding that the provision for collective wants must then be arbitrary, he warned against such "partial planning" which would "subvert the democracy" since individuals would not always be able to exercise and express their rational judgment.

In defending the requirement of compulsion for the public economy against Neal's criticism, Musgrave (1941) argued that, because of the possibility of free riding, no unanimous vote could be expected for the provision of collective goods. Requiring unanimity would lead to total inaction and would, furthermore, prevent any redistributive policies being accepted. The explicit argument is provided by Musgrave in a footnote: "[T] he individual members of the community will attempt to minimize their contributions, knowing that they can not be excluded [my emphasis] from the benefits. Cf. Musgrave, op. cit., p. 219, note 5" (Musgrave 1941, 320, n.4). This last remark in which Musgrave refers to the famous footnote of his 1939 paper is the first occurrence in his writings of the idea that voluntary provision (i.e., market allocation) of collective goods will fail because of the impossibility of exclusion.

In the same paper, Musgrave formulates the core idea of his normative approach to public finance that was already set forth in his (unpublished) dissertation:

I am aware that my model offers no realistic theory of a descriptive sort, but it is realistic in the sense of pointing towards an attack on the real issues of present day public finances. The planning model expresses the rationale of efficient government; it supplies us with a norm against which the accomplishments of our actual revenue-expenditure process may be checked (ibid., 324). 


\section{A turning point for the theory of public expenditures}

\subsection{The first half of the 1950 s}

During World War II, Musgrave was in charge of the fiscal policy affairs at the Board of Governors of the Federal Reserve (Musgrave 1997). The possibility of a contraction following demobilization was a preoccupation shared by many American economists working in government agencies (Backhouse 2015, 341). Public expenditures for stabilizing the business cycle was a new concern for Musgrave. Public works and other government transfers to sustain demand in times of crisis had to be chosen "on their own merits" (Musgrave 1945, 14), but a specific micro rationale was still lacking. The arguments to justify public funding for some goods over others were still interwoven.

Retrospectively, this confusion is also visible in other writings of the 1940s. For instance, Bowen (1948), who refers to Musgrave (1939) among many other eclectic sources, argues that social goods are indivisible and non-excludable, but he seems to confound the two ideas:

The goods for which price exclusion is impracticable are characterized by the fact that they cannot be divided up into units which any single individual can be given exclusive possession. They are, in this sense, indivisible. Such goods have the characteristic that they become part of the general environment-available to all individuals who live within that environment. They are, in that sense, social rather than strictly individual goods (Bowen 1948, 173).

At Michigan during the 1950s, Musgrave "resumed the problems of [his] thesis and formulated [his] ideas on the nature of the public sector" (Musgrave $1986 \mathrm{p}$. ix), which led to the publication of The Theory of Public Finance at the end of the decade. There is little evidence of Musgrave's progress in this work. Peacock $(1953,1992)$ recalls having read a 
draft of the Theory when he first met Musgrave in 1953. A department report from 1954

notes that "Richard A. Musgrave is currently completing a volume devoted to a reevaluation and synthesis of existing theories of monetary and fiscal policies."13 A year later, Samuelson $(1955,334)$ refers to a preliminary version of Musgrave's Theory to which he had access. In the spring of 1955, Musgrave wrote to Peacock that he expected to have finished the manuscript by the end of the year. It is not clear why the manuscript was only submitted to McGraw Hill more than two years later. ${ }^{14}$

Samuelson's (1954) paper certainly had an effect on Musgrave's thinking on public goods. The three-page paper pretentiously titled 'The pure theory of public expenditure'15 is presented as an appendix to his Foundations (1947) and was written to prove that mathematics can be useful in economics (Pickhardt 2006). ${ }^{16}$ In it, Samuelson derives the

13 Survey of the behavioral sciences: report of the faculty committee and report of the visiting committee. Ann Arbor, University of Michigan, 1954, p. 38.

14 Musgrave to Alan Peacock, March 16, 1955. Alan T. Peacock Papers, ms38965/9/2, University of St Andrews. Musgrave planned to spend the 1955-1956 academic year on sabbatical leave to finish the manuscript, before spending a few months in Europe (Musgrave to Peacock). But in May 1958, he wrote to Samuelson that the manuscript would go to press soon and that he expected to receive proofs by September (Musgrave to Samuelson, May 29 1958, PAS Papers).

15 In an unpublished response to critics of his 1954-1955 papers, he admits: "All agree that my paper was pretentious. While the critics agree that I am crazy in thinking myself to be Napoleon, they differ among themselves in their reasons, since a sizeable fraction think themselves to be Napoleon. I once thought that if only I had omitted the word 'the' from my title 'The Pure Theory of Public Expenditure' most of my punishment could have been avoided. But doing that in the second paper got me nowhere, and it availed me naught to give at the 1955 Xmas Meetings the most neutral title possible-namely Some Aspects of An Abstract model of Public Expenditure Theory [Samuelson (1955)].” 'Response to Critics of his 1954-55 Papers on Public Expenditure', undated, PAS Papers, Duke University, Unpublished Writings, Box 143.

16 Unpublished comments of Samuelson not available to Pickhardt (2006) corroborate his thesis: "My 1954 paper did pay proper acknowledgments to my predecessors, particularly Wicksell, Lindahl, Musgrave, and Bowen. But its austere brevity was conditioned by an epigrammatic demonstration of the usefulness of mathematical symbolism." 'Public Goods Twenty Years Later', June 1974, PAS papers, Box 143. 
necessary conditions for Pareto-optimal allocation in the presence of collective consumption goods. For each of them, the total quantity of the good in the economy is the quantity consumed by each and every agent. ${ }^{17}$ In other words, the same unit of good is collectively and simultaneously consumed by all agents in the economy, which means that "each individual consumption of such a good leads to no subtraction from any other individual's consumption of that good" (Samuelson 1954, 387).

By deriving the necessary conditions for optimal allocation, Samuelson (1954) fully integrated the concept of collective (public) good into the framework of the New Welfare Economics (Musgrave 1969b, 798). It is one of the first steps in the mathematization of public finance and its transformation into public economics. As Musgrave $(1983,324)$ later acknowledged, it contributed to changing the focus of the subfield, from a description, or a rationalization of what the state was doing, into a study of efficiency conditions in the face of market failures (on which see also Johnson 2015c).

Samuelson's (1954) paper was indeed a game-changer in the theorization of public expenditures, but it relied on previous conceptual work by Musgrave. In his own words: "All I ever knew about the Wicksell-Lindahl Paradigm of Public Goods, I learned only from Musgrave's 1937 Ph.D. dissertation" (Ott et al. 2008, 333). ${ }^{18}$ Seventy years after, Musgrave seemed to remember the discussions he had with Samuelson on the nature of public goods:

17 Rather than summing up the quantities as one would do for private goods, one gets $\mathrm{X}=$ $\mathrm{X}^{\mathrm{i}}$ for all agent $\mathrm{i}$.

18 In an unpublished paper, Samuelson gives a slightly different version of the story: "All I knew of Lindahl's 1919 German and Swedish text was a vague remembrance of one diagram from Richard Musgrave's 1938 Quarterly Journal summary of his Harvard thesis on the voluntary exchange theory. However, this diagram is really all one needs to know about Lindahl." 'Public Goods Twenty Years Later', June 1974, PAS papers, Box 143. p. 1. As early as the 1960s, Head $(1962,198)$ 
I (Richard) especially thank you for the inspiration you gave to those of us who attended Alvin's seminar in the late '30s. I vividly recall a conversation with you on our way from Littauer to the Faculty Club on whether nonrival consumption or nonexcludability serves as the crucial distinction between public and private goods. ${ }^{19}$

Musgrave's wife also recalls such discussions: "I well remember Richard and Paul getting together on a Sunday morning to discuss the solution to the provision of social goods." 20

As a matter of fact, Musgrave and Samuelson maintained a life-long friendship. ${ }^{21}$ They held each other in high esteem. When Samuelson was asked to provide advice on Musgrave for grant applications, or university appointments, he always spoke highly of him: "Musgrave and Boulding are the jewels in Michigan's crown and it will be a grievous loss to them if you should attract him away" (Letter to Garner, Johns Hopkins, 1958). In recommending Musgrave for a second Guggenheim Fellowship, he wrote: "Professor Musgrave is undoubtedly the authority in the whole field of public finance" (Letter to Ray, 1964). After Musgrave passed away, Samuelson remarked: "Whether at Swarthmore or Michigan or Hopkins or Princeton or Harvard, if Dick was there, he sat at the head of the

remarked: "Stimulated by the researches of Professor Musgrave. Samuelson has now opened this still far-from-empty box, and has set loose upon an ill-prepared literature a fully fledged mathematical theory of public expenditure, based upon this concept alone."

${ }_{19}$ Richard and Peggy Musgrave to Samuelson (on the occasion of his 90th birthday), May 20 2005, Correspondence', PAS Papers, "Musgrave, Richard, 1945-2007 Box 54".

${ }^{20}$ In a letter to Wallace Oates, she also wrote: "As Paul Samuelson has often pointed out, his own seminal paper on public expenditures grew out of Richard's work on public goods many years before, which they had discussed a number of times." Peggy Musgrave to W. Oates, July 122008. RAM Papers, 'Correspondence', Box 3.

21 They met at Harvard when Samuelson arrived in 1935. From 1937 to 1955, they both participated regularly in the Fiscal Policy seminar directed by John H. Williams and Alvin H. Hansen in the Littauer building at Harvard ("Official Register of Harvard University", http://www.irwincollier.com/harvard-economics-hansen-and-williams-fiscal-seminar-1937-

1944/). In the 1950s, Samuelson and Musgrave were both part of the Fineletter group, a circle of economists advising Democratic candidate Adlai Stevenson II (Schlesinger and Harris 1957, p. xx). 
round table" (2007). Musgrave, for his part, considered Samuelson "the greatest economist of the 20th century."22

If Musgrave and Samuelson discussed public goods theory in the 1930s, there is unfortunately no trace of Musgrave's writing on the topic between his 1941 paper and the first exposition of his Theory published in 1957. But it is likely that Musgrave had drafted material for the first chapter before Samuelson published his paper. In the aforementioned letter to Peacock from 1955, Musgrave remarked: "You may have seen a recent contribution by Samuelson in the Review of Economics and Statistics for November 1954, proceeding much along the same lines as I did, but of course, with more mathematical elegance." Perhaps Musgrave was referring here to the manuscript Peacock had read when they met in $1953 .{ }^{23}$

At the annual convention of the American Economic Association in December 1955, Musgrave and Samuelson co-organized a session (jointly sponsored by the Econometric Society) on the Theory of public expenditures. Musgrave presented a paper in which he set forth the basic structure of his normative Theory in three branches (the service branch, the distribution branch, and the stabilization branch) that correspond to the three main

\footnotetext{
22 Respectively, Samuelson to W. R. Garner, May 9 1958; Samuelson to Gordon N. Ray, December 1964; Speech at Harvard Memorial Chapel, May 18 2007, 'Correspondence', PAS Papers, "Musgrave, Richard, 1945-2007 Box 54"; and Musgrave interviewed by Karen I. Horn. published in the Frankfurter Allgemeine Zeitung, March 26, 2006. RAM Papers, Box 7.

23 The quote is from the letter from Musgrave to Peacock, March 16, 1955. Alan T. Peacock Papers. University of St Andrews. In a paper published two year earlier (in French), Peacock $(1953,442)$ wrote: "The discussion of the theory of collective wants that he [Musgrave] introduces in his Principles of the Public Economy (forthcoming) is extremely original and interesting." (my translation)
} 
functions of the public budget. ${ }^{24}$ Each branch performs its function on the assumption that the two others will meet their objectives. For the service branch, which is responsible for determining the goods and service that must be provided to satisfy public wants, this means that a "proper" state of distribution has been secured by the distribution branch and that full employment is guaranteed by the stabilization branch. This implies that the service branch can balance its budget, or that public services can be provided according to the benefit principle that links revenues and expenditures together. With the exception of merit wants, which arise out of a problem of separating the service and the distribution branch in the case of transfers in kind.

Musgrave had changed his view on the nature of public wants. Rather than being homogenized at the social level by the social planner, he assumed from now on that they are individual wants. Contrary to what he argued in his dissertation, and moving closer to the voluntary exchange theorists, he now claimed that both private and public wants "are part of one and the same subjective preference systems of individuals" (Musgrave 1957a, 334), the main difference between the two being that "goods and services supplied in the satisfaction of public wants must be consumed in equal amount by all [original emphasis]" (ibid.) This change of assumption reflects both the increasing hold of methodological individualism in welfare economics, and more generally the reformulation of all branches of economics into the language of market theory. The social perspective, or the collective interest, had to be conceptualized in strictly individualistic terms, as exemplified by Samuelson's discussion on welfare economics in his Foundations (1947) and Buchanan's

24 Samuelson presented a paper titled "Aspects of the Abstract Theory of Public Expenditures" which would be published in 1958 ("Report of the New York Meeting. December 27-30, 1955, Econometrica, 24(3): 338-353). 
(1949) "individualistic approach" to government finance. Moreover, to the extent that the market became a benchmark, individual valuations were basic to the demand side. ${ }^{25}$

Musgrave (1957a) draws two inferences on social wants. First, if a voluntary solution were possible, then the aggregate demand curve for an indivisible good must result from the vertical addition of the individual demands (that is for a fixed quantity of the good, the individual monetary contributions are added up). This result can be derived from Lindahl's (1919) model and was stated in those terms by Bowen $(1943,1948)$ and later restated by Samuelson (1955). Second,

since the same amount will be consumed by all, individuals know that they cannot be excluded from the resulting benefits. This being the case, they are not forced to reveal their preferences through bidding in the market. The "exclusion principle," which is essential to exchange, cannot be applied; and the market mechanism does not work (Musgrave 1957a).

In this quotation, Musgrave draws a causal explanation of market failure from the distinctive character of public wants. Clearly here both the indivisibility or jointness, and the impossibly of exclusion are linked together. ${ }^{26}$ Musgrave infers non-excludability from the jointness dimension of public wants. ${ }^{27}$ In a sense, this claim is tautological. If somebody were excluded, then there would be at least one individual not consuming the good,

25 This is typical of the postwar theory of market failures, as for instance in the conceptualizations of externalities (see Medema 2015).

26 Head (1970) remarked that indivisibility is a confusing all-encompassing criterion, but, as Ver Eecke (1999) has argued, it is closer to non-rivalry than to non-exclusion. To put it briefly, to say that the same unit of a good is consumed collectively and cannot be divided is equivalent to saying that the consumption of this unit is non-rival, or that one's enjoyment does not subtract any benefit from another's enjoyment of the same good.

${ }^{27}$ In a paper presented the same year at hearings of the JEC (US Congress), Musgrave (1957b, 110) defends a similar view. 
therefore it would not be a public good according to this definition. ${ }^{28}$ Thus, knowing that they cannot be excluded, individuals will not be forced to reveal their preferences and the market fails both as a mechanism of preference revelation (to know which goods in what quantity must be produced), but also-as was already clear in 1939-as a way to pay for the goods.

\subsection{The effect of Samuelson's paper}

As it has been expounded, Musgrave's definition of public wants in 1955/1957 clearly reflects Samuelson's definition of "equal consumption by all." Moreover, his shift to a more individually based assumption about public wants probably also reflects Samuelson's transformation of Lindahl's model into necessary conditions for optimal provision, but without the assumption of voluntary provision. As he put it: "our view borrows from Lindahl's formulation provided that we interpret it as an optimal result and not as an operational solution" (Musgrave 1957a, 335). Yet, this new result probably changed neither Musgrave's nor Samuelson's general view about the role of the government in society. After Musgrave's 1939 intuition about free riding, it provided another important step in the construction of a convincing argument for public funding of some goods and services. Musgrave and Samuelson held on to their view in the face of criticism from defenders of free market economics. As some market-like arrangements emerged to criticize the market-failure diagnosis, Samuelson expressed doubts towards them.

28 This argument was stated (in different terms) by Head $(1962,205)$. This ambiguity can be resolved if "consumed in equal amounts by all" is replaced by non-rivalry, or if one introduces another dimension such as the size of the interacting group, something that neither Musgrave nor Samuelson did explicitly. 
Commenting on Tiebout's (1956) model, in which taxpayers express their preference for public goods by voting with their feet, thereby recreating a market-like voluntary system, Samuelson asserted his moral repulsion at the consequences of the model:

People want to "improve" their community, not abdicate from it. Secondly, people often like heterogeneity even though it involves conflict. [...] In an interdependent world, one man's privacy is another man's condemnation to loneliness. Thirdly, there is the political and ethical question whether groups of like-minded individuals shall be "free" to "run out" on their social responsibilities and go off by themselves. At the national level, society respects no such freedom: e.g., migration control, compulsory taxation, etc. (Samuelson 1958, 337) ${ }^{29}$

Although Samuelson built for himself an identity of a technical value-free expert (Maas 2014), at times, his values are apparent in his analysis. In an unpublished paper, Samuelson uses a slightly irritated tone to reiterated his view that market arrangements cannot work for public goods:

This last finding of the theory was resisted by many modern writers (such as S. Enke, J. M. Buchanan, Charles Tiebout, Ronald Coase, and Milton Friedman) just as Wicksell, Lindahl, and older writers had unsuccessfully wrestled with the same issue. Still a logic is a logic and facts are facts. No one of the writers named, or anyone else to my knowledge, has been able to refute the theorem: [...] there is no decentralized algorithm (pricing or otherwise) that will both define an equilibrium and (without central intelligence or coercion) motivate individuals to achieve it. If this fact about the universe be deemed a sad fact, it is not one of my making. Nor is it a new fact: it existed even before 1776; only our full knowledge of it is new. ("Public Good Theory: Optimal Feasible Pricing of Rail, Bridge, and Road," rough draft 7 Feb. 1964, PAS Papers.)

Here, Samuelson is trying to support his interventionist position (on which see Horn 2009)

by invoking positive arguments. Perhaps Samuelson would not go as far as Musgrave in

29 Tiebout first discussed his model in Musgrave's public finance seminar at Ann Arbor (Fischel 2006). Although Musgrave was somewhat proud of this, he was very critical about the applicability of the model (Buchanan and Musgrave 1999, 158). On Tiebout, see Singleton (2015). 
arguing that collective choice through voting can solve the problem, but at least he identifies the enemies: Buchanan and Coase, among others.

Musgrave $(1983,328)$ shared Samuelson's doubts about the possibility of a marketlike revealing mechanism. As I have argued, Musgrave already held that the state had a positive role to play in the welfare of the citizens. Samuelson's model served as a step in the construction of a convincing argument for economists. Even though it did not convince everyone, public provision of collective goods was a widely accepted view in the 1960s, until attitudes about the government's ability to deliver on its promises slowly began to change among economists in the 1970s (Bernstein 2001, Chapter 6; Backhouse 2005; Madra and Adaman 2010; Tanzi 2011, 134). In a sense, the theory of public goods is a rationalization of values and worldviews that were not uncommon at the time of increasing governmental responsibilities in the welfare of American citizens. In 2004, Musgrave served as blind referee for Pickhardt's (2006) paper published in the Journal of the history of economic thought. At the end of his report, he noted how, in retrospect, Samuelson's model had the effect of providing another argument for market failure that fitted the spirit of the time:

As the author notes, the bombshell effect of Samuelson's first paper was to be explained by its theoretical brilliance of presenting the complex issue of public goods in so succinct a form. But there may have been more to it. Even findings of pure theory may have their ideological settings and the existence of public goods seemed to offer the penultimate cause of market failure, questioning the role of the market as the universal and natural solution to human coexistence. In the ' 50 s, this critique still appealed to a liberal political climate, following earlier critiques by Joan Robinson, Keynes, Samuelson, Hansen, and others. ${ }^{30}$

\footnotetext{
30 "Comments for author," Musgrave to Medema (Editor of JHET), June 7th 2004, RAM Papers, Box 3, 'Papers other'. Quotation with permission from Steven G. Medema. Michael Pickhardt passed away in 2012.
} 
In as much as a model is a rationalization of contemporary concerns held by citizens, political leaders, or economists, it is hard to separate its positive value from the normative narrative that might be derived from it. ${ }^{31}$ In a sense, Samuelson's abstract model is a thought experiment that rationalizes government provision of certain goods in the language of modern economics. In this simplified world, the reader discovers that when the state's coercive power is assumed away, collective goods are not provided in sufficient quantity to reach a social optimum.

\subsection{Musgrave's Theory of Public Finance (1959)}

Although Musgrave's definition of social goods in the 1950s reflected Samuelson's influence, he still believed that non-exclusion was the main argument for their public provision. Reflecting on the past 20 years of debate, Head $(1977 a, 228)$ remarked that:

Beginning with his 1958 paper [16, p. 335], Samuelson has, however, repeatedly insisted that the jointness characteristic is in some sense more basic than impossibility of price exclusion, and there is some evidence that he has converted both Musgrave and Buchanan to this point of view.

Head did not provide evidence for his claim, but I have argued that Musgrave and Samuelson had discussed the matter before 1958. In fact, Samuelson kept the comments he made on Musgrave's draft of the first part of his Theory, which likely go back at least to 1955. One of Samuelson's main contentions is on the nature of public goods:

31 Similarly, twenty years before Samuelson's paper appeared, Einaudi $(1934,26)$ remarked that De Viti de Marco's Principles of Public Finance was a "reflection" in the field of public finance of the transition to more democratic/popular government over the nineteenth century in Italy. This reflection took the form of "fundamental types" abstracted from the facts. This view is also expressed by Myrdal (1930,157): "All normative economic doctrines are largely rationalizations of political attitudes and in the theory of public finance probably even more than elsewhere because stronger political pressures are at work here." 
I think your emphasis on the "exclusion principle" is extremely important. However, I think at some later point I should want further discussion and a number of further distinctions to be made. [...] Quite aside from any narrow interpretation of the exclusion principle, the existence of such a condition as decreasing costs will not only make perfect competition non-viable as a predictive statement, but it will also create normative inadequacies of the market mechanism. ${ }^{32}$

Thus, Samuelson (1955) argued that collective goods in the sense he defined them were a specific case of the more general problem of decreasing costs, the latter being the proper reason for departing from the rule of pricing at marginal cost. He continues:

Your paragraph dealing with joint consumption seems to me to be not completely satisfactory. Concerts are a wonderful example of decreasing cost situation in which optimal pricing according to marginal cost might require that you set zero prices. [...] If you could find a way of learning when people listen in to the radio, you might apply the exclusion principle to this area. Yet, you would be wrong in discouraging people from getting more satisfaction from listening in an extra hour when there is no true cost to society of their listening in that extra hour. Something like joint consumption is the essence of governmental services. Or to put the matter in reverse way: the market mechanism and the exclusion principle work well only in the very special case where there happen to be no 'external' effects on the consumption side.

Samuelson's argument to convince Musgrave is already clear: In the case of a good which can be provided at zero (or small) marginal cost, even if exclusion was feasible, it would not be Pareto optimal to impede another user from the benefit of the good. ${ }^{33}$ Hence, it is "jointness in demand", or "external economies" (Samuelson 1954) or "decreasing cost" (Samuelson 1955) that account for the market failure of public goods, according to Samuelson. This argument would be stressed by Samuelson over and over again.

\footnotetext{
32 "Detailed comments on PRINCIPLES OF THE PUBLIC ECONOMY." Undated, but inserted in a chronologically ordered folder between a letter from 1951 and another from 1955. It seems reasonable to date this 6-page document at the latest from 1955, recalling that Samuelson (1955, 354) noted: "I have greatly benefited from preliminary study of Professor Musgrave's forthcoming treatise on public finance, which I am sure will constitute a landmark in this area.", PAS Papers, 'Correspondence', "Musgrave, Richard, 1945-2007 Box 54"

33 This argument was already formulated by Buchanan $(1951,174)$.
} 
In the published version of the Theory, Musgrave renames the service branch as the allocation branch. Its function is to provide for the satisfaction of public wants, which are of two kinds: social wants and merit wants. Notice the slight difference from the previous definition given in 1957a:

Social wants are those wants satisfied by services that must be consumed in equal amounts by all. People who do not pay for the services cannot be excluded from the benefits that result; and since they cannot be excluded from the benefits, they will not engage in voluntary payments. Hence the market cannot satisfy such wants. Budgetary provision is needed if they are to be satisfied at all. (Musgrave 1959, 8)

Here, the impossibility of exclusion is not inferred from the jointness in consumption. Musgrave argues that this specificity leads to two problems. First, preferences will not be revealed, hence the government has to find a way to "induce" citizens to reveal them. Second, even if preferences were known, contrary to market functioning, there is no single given optimal solution. Thus a social welfare function is required to select the desired state of distribution. ${ }^{34}$ Musgrave adds some further clarification on social wants: "[S]uch wants cannot be satisfied through the mechanism of the market because their enjoyment cannot be made subject to price payment" (ibid., 9, my emphasis). In the case of private goods, property rights entitle the owner to exclude others from enjoying the benefits she derives from the good. This is what Musgrave calls "the exclusion principle" and it does not apply in the case of social wants. Hence, Musgrave (1959) believed that it is the impossibility of exclusion that is the cause of market failure. ${ }^{35}$

\footnotetext{
${ }^{34}$ Head and Samuelson remarked that Musgrave is wrong on this, since even in a world of purely private goods, there is rarely a single optimum.

35 As early as the nineteenth century, Wagner $(1892,419)$ had argued that there was an exclusion problem for public services. Mazzola $(1890,42)$, who referred to the second edition of Wagner's Grundlegung, identified a technical characteristic to explain the public provision of some goods,
} 
As in the 1939 and 1941 papers, the most important remarks on social goods in the

1959 book are to be found in a footnote:

It is evident that the case of social wants must involve joint consumption, but joint consumption, as usually defined, does not necessarily involve social wants. A circus performance involves joint consumption on the part of those who attend. Yet entrance fees can be charged, different amounts can be consumed by various people and the service can be provided through the market. Demand schedules can be added horizontally. (See p. 76). For a social want to arise, the condition of equal consumption must apply to all, whether they pay or not. In other words, we must combine the condition of joint consumption with that of inapplicability of the exclusion principle. Only then will demand schedules be added vertically. (ibid., 10 n.1)

For the first time, it is clearly stated that two conditions must be met in the case of social wants-which on consistency grounds should have called for a rewriting of the definition of social wants given earlier. This fact becomes evident in the case of an outdoor circus, which was one of the two examples of public goods, along with national defense, given by Samuelson $(1955,350)$. Musgrave argued that circuses, contrary to national defense, do not result in market failure in the sense that private organizations can repay their costs without the help of the state. Hence, there must be another necessary condition for market failure in the case of social wants, namely impossibility of exclusion.

Finally, Musgrave reckons that, since voluntary payments are not possible, public services satisfying social wants must be provided free of direct charge (ibid., 15). Since the distribution and stabilization branches are assumed to meet their objectives, funding for those services can follow the benefit principle. In practice, this would imply a proportional tax if the income elasticity of demand is around one. If it is larger than one, then the tax would need to be progressive, and if smaller than one, regressive.

namely their indivisibility. Yet, he also noted that this fact entailed the impossibility of "debarring" users from the consumption of those goods. 
Clearly, Samuelson could not have been satisfied with the final version of Musgrave's Theory. In an unpublished draft (1959) intended as a friendly criticism of Musgrave, he argued again:

The important question is not whether we can exclude someone from use or enjoyment of a public good, but rather whether in excluding it from one man we thereby make as much more of it available to other men. What makes bread a private good is that when a loaf goes into my stomach, it thereby becomes unavailable for your stomach. [...] Of course, we could put a toll collector on an uncrowded road and charge fees. But should we? ${ }^{36}$

Musgrave (1959) acknowledged Samuelson's point in a chapter titled "Further problems in efficiency". He saw the case of an uncrowded bridge as a "paradoxical situation" where the exclusion principle could be applied, but that doing so would result in an "inefficient solution" because of very low marginal costs (Musgrave 1959, 138). Still, as long as the bridge was funded by toll, Musgrave did not see it as a case of social good. ${ }^{37}$

\section{Crystallization of the two criteria}

\subsection{Refinement of a theoretical question in the $1960 \mathrm{~s}$}

In the 1960s, numerous papers were published on the definition of public goods and their implications for efficient allocation. Although Musgrave (1959) had argued in the abovequoted footnote that two conditions must be met, it was not at all clear at the beginning of

\footnotetext{
36 "More on public goods and bads: a road case,"1959, PAS Papers, Unpublished Writings, Box 142. The argument is repeated in "Public Good Theory: Optimal Feasible Pricing of Rail, Bridge, and Road," rough draft Feb. 7 1964, PAS Papers, Unpublished Writings, Box 143. It is also stressed in a debate on Subscription TV between Samuelson $(1958,1964)$ and Minasian (1964).

37 He conceded to see it as a social good only if it would be funded by general taxation, or, more convincingly, it it produced «collateral benefits » to the neighboring residents (Musgrave 1959, p. 139).
} 
the decade that two criteria had to be defined. Probably convinced by the persuasiveness of his free riding argument, Musgrave held on to non-exclusion as the most important characteristic of social goods for most of the 1960s (see Musgrave 1962, 109; 1964, 4; 1965, 3).

In 1966, Musgrave presents a paper titled Provision for social goods, in which he reviews "the polar case of a pure social good" and then suggests some generalization to mixed goods. The author explains the shift in his phenomenological view point: "To emphasise that the distinguishing characteristic derives from the nature of the good, rather than the utility function, I now prefer the term social good to my earlier terminology of social want" (Musgrave 1969a, 126). Musgrave then proceeds to (re)define social goods: "The first is the characteristic of non-rivalness in consumption, i.e., the existence of a beneficial consumption externality. The second is the characteristic of non-excludability from consumption. The two are distinct features and need not coincide. Each plays a different role" (ibid.) This is the standard textbook definition that is still used today.

Musgrave then explains that non-rivalness, the fact that the consumption by one individual does not reduce the benefits enjoyed by another individual while consuming the same good, is responsible for the vertical addition of demand curves. It is also this characteristic that leads to the different necessary condition for optimality that Samuelson (1954) derived. Incidentally, Musgrave (1983, 332, n.7) acknowledged that it was Samuelson's $(1955,356)$ claim that there exists some "element of variability in the benefits that can go to one citizen at the expense (Musgrave's emphasis) of some other citizen" which led him to coin the term non-rivalness in consumption (Pickhardt 2006). 
Musgrave again states that non-excludability of social goods leads to a difficulty in revealing preferences. National defense combines both characteristics, but some goods exhibit only one of the two. For instance, the orchard that benefits the nearby bees gives rise to a rival consumption (there is a depleting amount of nectar available to many apiarist neighbors), but the market fails because of the impossibility of exclusion, or of very high exclusion cost. On the other side, an uncrowded bridge is a non-rival good, but exclusion and toll charging is possible. Now, Musgrave argued that it is not efficient (Pareto-optimal) to exclude anyone from the consumption of such a good since she would benefit from it at no additional cost. Hence, at this point, Musgrave had accepted Samuelson's argument. ${ }^{38}$

With the given definition of non-rivalness as externality in consumption, Musgrave (1969a) extends the polar case to mixed cases by resorting to variations in the characterization of the utility function of two consumers. For agent A, the polar case is $\mathrm{U}_{\mathrm{A}}=\mathrm{U}\left(\mathrm{X}_{\mathrm{A}}, \mathrm{Y}\right)$ where $\mathrm{X}_{\mathrm{A}}$ is a private good and $\mathrm{Y}$ is a social good and $\mathrm{U}_{\mathrm{B}}=\mathrm{U}\left(\mathrm{X}_{\mathrm{B}}, \mathrm{Y}\right)$ for agent B. If $\mathrm{Y}$ is a partially social good, then the part paid by A might not affect B as much as it benefits $\mathrm{A}$. This would be the case for water treatment by two neighbors living along a waterway. By splitting the respective part paid by the two agents, one can thus rewrite $Y=Y_{A}+Y_{B}$ and allow variation in the intensity of the benefits that accrue to one agent, for example by letting $\gamma$ vary in $\mathrm{U}_{\mathrm{A}}=\mathrm{U}\left(\mathrm{X}_{\mathrm{A}}, \mathrm{Y}_{\mathrm{A}}+\gamma \mathrm{Y}_{\mathrm{B}}\right)$ and likewise for agent $\mathrm{B}$. The author analyzes all the seven cases and summarizes them in a $4 \times 4$ table in which the polar case of pure private good lies in one corner and the pure social good in the other diagonally opposing corner.

38 It is also clear from Musgrave $(1969,799)$. 
When it became clearer that two independent criteria were at stake, one of the points of contention became which was the most important characteristic, when they were both present. As Samuelson argued in his paper presented at the same conference:

This may be a convenient place to note, for the interested reader, the few places where a close reading of Musgrave leads to disagreement between us. The possibility or impossibility to apply an 'exclusion principle' is less crucial than consumption externality, since often exclusion would be wrong where possible.

Yet, Samuelson also acknowledged that "Many of my criticisms are met by the reformulations of Musgrave in his paper for this conference [1969a]; and from neighbourly conversations I know that we are in basic agreement on most issues" (ibid).

Musgrave's narrative on public goods takes its definite textual form in a synthesis of the discussion he published in 1971. What is new in this paper is that in cases where "two causes of market failure overlap," like in lighthouses, the more basic one is "the nonrival nature of consumption", because "(in the efficient system) we would not wish to apply exclusion even if we could do so in this case" (Musgrave 197, 307)..$^{39}$ In sum, at the end of the decade, Musgrave arrived at the conclusion that there were potentially two distinct causes of market failure in social goods, but, when they overlap, he agreed with Samuelson that non-rivalry was more basic than non-exclusion. This last point is important if we look at Musgrave's conceptual work on social goods as an attempt to justify public provision. From this perspective, non-rivalry constitutes a definitive argument for public provision. Non-exclusion explained why individuals would free ride, but if exclusion devices can be designed, as would be the case for television, the argument for public provision would fade away. This contingency did not affect the non-rivalry dimension that, when seen as

\footnotetext{
39 Musgrave had already argued in 1968 that joint consumption was the 'most basic' case, but he did
} not used the expression of non-rivalry. 
decreasing cost, would not be tempered by new technological development. As long as Pareto-efficiency was a goal of political representatives, free provision of social goods would be called for.

Other factors might have played a role in Musgrave's conversion. In a book review of Musgrave's Theory, Buchanan $(1960,237)$ already criticized Musgrave's reliance on this criterion: "the impossibility of exclusion is not a necessary condition for collective action in satisfying a genuinely 'social want'." More generally, Buchanan's (1965b) approach is to minimize the importance of exclusion problems. If in the majority of real-word cases exclusion is not impossible, then some 'joint' goods can be efficiently provided by smallscale clubs. Recognizing the large-number dilemma, Buchanan's (1965a; 1968) strategy is to factor down interactions to small groups where strategic bargaining can lead to the best result, provided that appropriate constitutional rules can be established among the parties. ${ }^{40}$ Moreover, following the seminal contributions of Coase (1960) and Demsetz (1964), many scholars tried to solve the problems of appropriability of services by properly designing and assigning property rights. This research program might have encouraged Musgrave to adopt another, more convincing, argument for public provision of social goods, although there is no direct evidence for this effect.

\footnotetext{
40 Marciano (2015) argues differently. He maintains that Buchanan recognized the necessity of grounding individual behavior in ethics to guarantee that social interactions always result in prosocial behavior, even in small groups
} 


\subsection{Public Finance in Theory and Practice}

Musgrave's definition of public goods formed the basis of a chapter in an undergraduate textbook co-written with his wife and published in $1973 .{ }^{41}$ The terminology and the arguments of the 1971 paper are reproduced with more examples of cases where both causes of market failure overlap, namely air purification, national defense, and street lights (Musgrave and Musgrave 1973, 54). Then the authors summarize the different possibilities in a $2 \times 2$ table (see Table 1 ).

\begin{tabular}{lcc}
\hline Consumption & \multicolumn{2}{c}{ Exclusion } \\
& Feasible & Not Feasible \\
\hline Rival & 1 & 2 \\
Nonrival & 3 & 4 \\
\hline
\end{tabular}

Table 1: Summary Table (source: Musgrave and Musgrave 1973, 54)

In this table, case 1 represents the private-good case where exclusion is possible and the consumption is rival. The authors then explain that:

[i]n all other cases, market failure occurs [...] If we applied the term 'social good' to all situations of market failure, cases 2,3 and 4 would all be included. It is customary, however to reserve the term for case 3 and 4, i.e., situations of nonrival consumption. (ibid.)

This table is found in many public finance and introductory microeconomics texts without reference to its origin. The tables found in the textbooks surveyed display examples of goods rather than numbers in the cells. The first occurrence of this practice appears in a

\footnotetext{
41 The 778-page book was re-edited in 1976, 1980, 1984 and 1989.
} 
chapter by Ostrom and Ostrom (1977) who do not make any reference to Musgrave and Musgrave (1973). This table is reproduced in the Appendix 1.42

The objective of the Musgraves' table is to give a first approximation of what ought to be done by the state, and at the same time introduce students to some of the issues that will be discussed in Public finance and Public economics. It helps to draw the line between a sphere of individual freedom and one of government funding and regulation. As a visual representation of the typology of goods, the table carries a simple narrative in which the state is responsible for restoring efficiency. This focus on efficiency is implicit in the discussion on public goods, and more generally in postwar theories of market failures (Marciano and Medema 2015, 11). Musgrave also acknowledged (and defended) the point that governments could act from different values or principles, especially equity and stability. His fiscal federalism framework is structured on this broader set of principles, as is the original allocation function of his Theory, which also included the provision of goods to satisfy merit wants. Yet, in this table efficiency is still the only objective considered.

The table is also representative of the changes of practice in textbook writing. After World War II, economics texts gradually contained more and more equations, graphics and tables (Solow 1997; Giraud 2010). In this sense, the Musgrave textbook is very modern and this explains its popularity. Yet, at the same time, the table represents a typology of goods characteristic of the old way of modeling in economics, especially in the German tradition.

\footnotetext{
42 Although there are resemblances to the Musgraves' table, the narrative which is attached to their table is very different. The Ostroms objective is to "explore the organizational possibilities for the public sector, including the development of marketlike arrangements. Such arrangements suggest an industry approach to public services, an approach with implications for public administration quite different from management and control through an overarching public bureaucracy." (Ostrom and Ostrom 1977, 164).
} 
Still, a qualitative typology that produced a diversity of cases allowed for a more realistic view, and an easier fit with the complex real-life situations faced by the public administrations and the political representatives, than a "knife-edge pole" of pure collective goods proposed by Samuelson. The different types of goods-including merit goods, which are not included in the table-rationalize the different types of government intervention (or non-intervention for private goods) in resource allocation. As Musgrave (1969a p. 142) put it: "semantics, as the history of economic thought so well shows, is not a trivial matter; and I remain persuaded that systematic explanation of non-polar situations will be helpful, as they may point to different policy solutions". For him, the concept of social (public) goods was one element within a comprehensive theory of the public sector. To be useful, Musgrave argued that the theory had to be realistic, which was not a decisive feature of Samuelson's model: “my model of pure public goods has turned out to be an unrealistic polar case" (Samuelson 1958, 336). In contrast with Musgrave's realistic concern, Samuelson appears as the romantic figure. He was contented with the belief that his model "would have vital policy implications," but he might not have thought it his responsibility to get involved in the details and derive a practical theory around it. ${ }^{43}$ For instance, Hammond (2015) observes that Samuelson did not discuss the theory of public goods in at least the first four editions of his Economics (1958).

43 Samuelson's occasional comments on the history of economic theory resolve around praising geniuses. See for instance the introduction to the second edition (1983) of his Foundations (1947), or his apology of Frank Ramsey (as discussed by Duarte 2010). Moreover, he acknowledged being driven by aesthetic ideals, notably in his contribution on collective goods: "My aesthetic sense was tickled by the beautiful duality displayed by public and private goods and their "prices" - the vertical addition of public-good "demands" as against the horizontal addition of private-good "demands," the " + and =" dualities." ("Public Goods Twenty Years Later," June 1974, PAS papers, Box 143. p. 2) 


\section{Conclusion}

Musgrave's conceptualization of social goods evolved over the 30-year period discussed here. In his dissertation, Musgrave (1937) stumbled upon the problem of assessing the individual benefits of social wants proper, which he singled out as being satisfied by indivisible goods. This point was not so original, but, as public expenditures were increasing, a better rationale for public provision had to be found. Because some goods were non-excludable, the voluntary exchange assumption was unrealistic, and the existence of a state with coercive power had to be assumed at the outset. Though Musgrave probably did not need this argument to convince himself of the beneficial role of the state, it provided what would become a convincing argument in the rational-choice mindset of the second half of the century. In the 1950s, the debate on the specificity of public expenditures took a new turn with the publication of Samuelson's paper. In the 10 years that followed, Musgrave's conceptualization of social goods was strongly influenced by the idea of "joint consumption by everyone," although he still held onto non-exclusion as the cause of market failure. During this time, Samuelson tried to convince Musgrave that the jointness dimension of collective goods was a more basic cause of market failure in the face of public goods. The definitive textbook definition of social or public good is given by Musgrave in his 1966 paper (published in 1969). Certainly, models in public economics use Samuelson's mathematical definition $\left(X=X^{i} \forall i\right)$, and the understanding of non-rivalry owes a lot to Samuelson's discussion on jointness in consumption. Still, it was Musgrave who insisted on the idea of two independent criteria that lead to a more comprehensive typology of goods. Even though this is still a stylized depiction, it is more realistic. 
The concept of public good (or social good) is thus an ideal type (Ver Eecke 1999) that can be represented in a table, along with some departures from it. Since it is an ideal concept, it is not to be directly found in the world. When trying to capture real-world public services with Musgrave's typology, some concessions must be made. For instance, implicit institutional constraints and political traditions are woven into every bottom-up fit. More generally, the market failure perspective in which this discussion took place can be interpreted as a rationalization of contemporary concerns about the role of Federal government and the growth of the welfare state. This technical debate on the specificity of public expenditures highlights the evolution of public finance in the middle of the twentieth century. The story is about the creation of a scientific argument based on a specific representation of the agent and its institutional setting, namely a selfish rational consumer who demands some goods that have special technical characteristics. This sophisticated argument enjoyed a certain popularity in the intellectual battle against more libertarianleaning economists, such as Buchanan, at least until the 1970s when the "pendulum" started to swing back to more unfavorable views toward the state. Yet, in the four decades of his life that followed the crystallization, Musgrave stayed loyal to his conception of social goods.

Over the 70 years of his career, Musgrave participated in the institutionalization of modern American public finance. One of the striking features of Musgrave's contribution lies in his educational reach. As Sturn $(2010,307)$ aptly remarked: "Musgrave's influence on modern Public Economics is an example of how the dissemination of innovations is 
enhanced by a suitable expository framework." 44 This is true in at least two ways. First, it is true directly, through teaching public finance in universities. As a matter of fact, the threebranches framework within which social goods find their place has always been praised as a useful pedagogical device to structure the discussion on market failures (R. A. Musgrave 1989; Solow in Ott et al. 2008; P. Musgrave 2008). Second, Musgrave's normative model of the public economy proved a useful representation in the broader economic literacy push in the postwar era. ${ }^{45}$ Musgrave wanted to contribute to a better society by designing a normative model of the public economy that would help to elaborate rational public policies and facilitate public debate on the role of government in society. With growing public expenditures, the state became increasingly important in the lives of the citizens. In this context, upholding democracy required that public policies be framed in clear language, to which Musgrave contributed with his definition of social goods.

\footnotetext{
${ }^{44}$ Likewise, Sinn $(2009,131)$ rightly noted that Musgrave "was too modest when he claimed that he just transported prior knowledge over the bridge he had built across the Atlantic. His writings were clearer and at the same time, more comprehensive than those of his predecessors."

45 For example, it constituted the basis of a paper presented in JEC hearings on Federal expenditures by the soon to be CEA president Walter Heller in 1957. On the role of the 1946 Employment Act and its offspring, the JEC and the CEA, see Hansen (1957, 81ff.) See also Council of Economic Advisers: Walter Heller, Kermit Gordon, James Tobin, Gardner Ackley, Paul Samuelson, recorded interview by Joseph Pechman, August 1, 1964, John F. Kennedy Library Oral History Program.
} 


\section{Appendix 1}

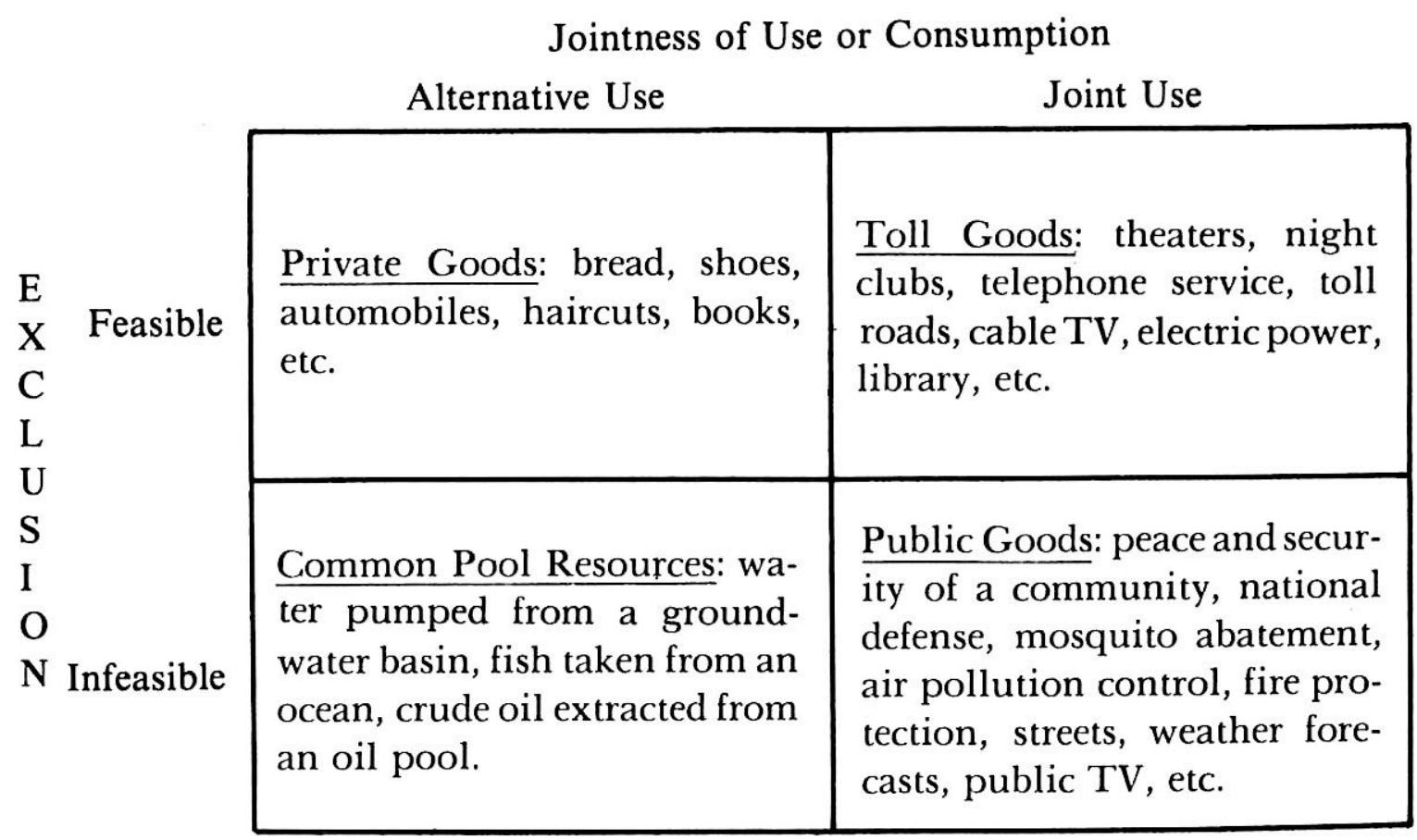

Source: Ostrom and Ostrom $(1977,12)$ 


\section{References}

Atkinson, Anthony B. 1987. The Collected Papers of Richard A. Musgrave. A Review Article. Journal of Public Economics, 33, 389-398.

Backhaus, Jürgen G., and Wagner, Richard. 2005. "From Continental Public Finance to Public Choice: Mapping Continuity. History of Political Economy, 37(S1), 314-332.

Backhouse, Roger E. 1998. "The Transformation of U.S. Economics, 1920-1960, Viewed Through a Survey of Journal Articles." History of Political Economy 30 (supplement): 85107.

- - 2005. "The Rise of Free Market Economics: Economists and the Role of the State Since 1970." History of Political Economy 37 (supplement): 355-92.

- _ - 2015. "Revisisitng Samuelson's Foundations of Economic Analysis". Journal of Economic Literature, 53(2), 326-350.

Baumol, William J. 1952. Welfare Economics and the Theory of the State. Cambridge, MA: Harvard University Press.

Benham, F. C. 1934. “Notes on the Pure Theory of Public Finance.” Economica 1 (4): 436-58.

Bergson, Abram. 1938. "A Reformulation of Certain Aspects of Welfare Economics." The Quarterly Journal of Economics 52 (2). Oxford University Press: 310-34.

Bernstein, Michael A. 2001. A Perilous Progress. Economists and Public Purpose in Twentieth-Century America. Princeton: Princeton University Press.

Bowen, Howard R. 1943. "The Interpretation of Voting in the Allocation of Economic Resources." The Quarterly Journal of Economics 58 (1): 27-48.

——_. 1948. Toward Social Economy. New York: Rinehart \& Co.

Buchanan, James M. 1949. "The Pure Theory of Government Finance: A Suggested Approach". The Journal of Political Economy, 57(6), 496-505.

$173-78$.

38.

- 1960. "Review : The Theory of Public Finance." Southern Economic Journal 26: 234-

___. 1964. “What Should Economists Do ?” Southern Economic Journal 30 (3): 213-22.

___. 1965a. "Ethical Rules, Expected Values, and Large Numbers." Ethics 76 (1): 1-13.

___ 1965b. “An Economic Theory of Clubs.” Economica 32 (125): 1-14.

___ 1966. "Joint Supply, Externality and Optimality." Economica 33 (132): 404-15.

—_- 1968. The Demand And Supply of Public Goods. Indianapolis: Liberty Fund. 
Buchanan, James M., and Richard A. Musgrave. 1999. Public Finance And Public Choice: Two Contrasting Visions of the State. Cambridge, MA: MIT Press / CESifo.

Coase, Ronald H. 1960. "The Problem of Social Cost." Journal of Law and Economics 3 (October): 1-44.

Colm, Gerhard. 1934. “The Ideal Tax System.” Social Research 1 (3): 319-42.

- _ - 1936. "Theory of Public Expenditures." Annals of the American Academy of Political and Social Science 183: 1-11.

Cornes, Richard and Todd Sandler. 1996. The Theory of Externalities, Public Goods, and Club Goods. Second. Cambridge University Press.

Craver, Earlene and Axel Leijonhufvud. 1987. "Economics in America: the Continental Influence." History of Political Economy 19(2): 173-182.

De Viti de Marco, Antonio. 1934. First Principles of Public Finance. London: Jonathan Cape. 1936. Reprinted 1950. Translated from Principi Di Economia Finanziaria.

Demsetz, Harold. 1964. "The Exchange and Enforcement of Property Rights." Journal of Law and Economics 7: 11-26.

Desmarais-Tremblay, Maxime. 2013. “On the Definition of Public Goods. Assessing Richard A. Musgrave's Contribution.” CES Working Papers, no. 2014.04.

- - - Forthcoming. "A Genealogy of the Concept of Merit Wants." The European Journal of the History of Economic Thought. http://dx.doi.org/10.1080/09672567.2016.1186202

Dougherty, Keith L. 2003. "Precursors of Mancur Olsen." In Collective Choice: Essays in Honor of Mancur Olson, 17-31. Springer.

Downs, Anthony. 1957. "An Economic Theory of Political Action in a Democracy." The Journal of Political Economy 65 (2): 135-50.

Duarte, Pedro. 2010. "Beyond Samuelson's Chapter on Ramsey." History of Economic Ideas 18(3): 121-159.

Düppe, Till and E. Roy Weintraub. 2014. Finding Equilibrium: Arrow, Debreu, McKenzie and the Problem of Scientific Credit. Princeton: Princeton University Press.

Einaudi, Luigi. 1934. "Introduction." In First Principles of Public Finance by A. De Viti de Marco. London: Jonathan Cape.

Fischel, William A. 2006. "Footloose at Fifty: An Introduction to the Tiebout Anniversary Essays." In The Tiebout Model At Fifty. Essays in Public Economics in Honor of Wallace Oates. Cambridge, MA: Lincoln Institute of Land Policy.

Fontaine, Philippe. 2014. "Free Riding." Journal of the History of Economic Thought 36 (03): 359-76. 
Fossati, Amedeo. 2003. "Public Goods in the Italian Tradition." Il Pensiero Economico Italiano 11 (1): 99-122.

Fausto, Domenicantonio. 2010. "Public expenditure in Italian public finance theory". European Journal of the History of Economic Thought, 17(4), 909-931.

Giraud, Yann. 2010. "The Changing Place of Visual Representation in Economics: Paul Samuelson Between Principle and Strategy, 1941-1955." Journal of the History of Economic Thought 32 (02): 175-97.

Gruber, Jonathan. 2011. Public Finance and Public Policy. Third edition. New York: Worth Publishers.

Hagemann, Harald. 2011. "European Émigrés and the 'Americanization' of Economics." The European Journal of the History of Economic Thought 18 (5): 643-71.

Hammond, J. Daniel. 2015. "Paul Samuelson on Public Goods. The Road to Nihilism." History of Political Economy 47(S1): 147-173.

Hansen, Alvin H. 1957. The American Economy. New York: McGraw-Hill.

Hardin, Russell. 2003. "The Free Rider Problem." In Stanford Encyclopedia of Philosophy. http://plato.stanford.edu/archives/spr2013/entries/free-rider/

Head, John G. 1962. "Public Goods and Public Policy." Public Finance / Finances Publiques 17 (3): 197-219.

-——. 1965. "The Welfare Foundations of Pub
Finanziario E Scienza Delle Finanze 24: 379-428.

- - 1 1970. "A Voluntary Exchange Theorie of the Public Economy." FinanzArchiv / Public Finance Analysis 29 (1): 112-21.

- - 1974. Public Goods and Public Welfare. Durham: Duke University Press.

———. 1977a. "Public Goods: The Polar Case Reconsidered." Economic Record 53 (2): 22739.

Heller, Walter W. 1957. "Economics and the Applied Theory of Public Expenditures." In Federal Expenditure Policy for Economic Growth and Stability. Papers Submitted by Panelists Appearing Before the Subcommittee on Fiscal Policy, 98-107. Washington DC: U.S. Congress.

Hindriks, Jean and Gareth D. Myles. 2006. Intermediate Public Economics. Cambridge, MA: The MIT Press.

Horn, Karen Ilse. 2009. "Paul A. Samuelson." In Roads to Wisdom, Conversations with Ten Nobel Laureates in Economics, 39-57. Cheltenham: Edward Elgar.

Johnson, Marianne. 2014. "Progressivism and Academic Public Finance, 1880 to 1930." History of Political Economy 46 (1): 1-32. 
- - 2015a. "Harold Groves, Wisconsin Institutionalism and Postwar Public Finance." Journal of Economic Issues, 49(3): 691-710.

- - - 2015b. "Public Goods, Market Failure, and Voluntary Exchange." History of Political Economy, 47(S1): 174-198.

- — . 2015c. "Dull, Unimaginative, and Extremely Limited" Becomes Modern Public Economics". Working paper.

Leroy-Beaulieu, Paul. 1906. Traité de La Science Des Finances. Paris: Guillaumin et Cie.

Lindahl, Erik. 1919. "Just Taxation-A positive solution." In Classics in the Theory of Public Finance, edited by Richard A. Musgrave and Alan T. Peacock, 168-176. London: Macmillan \& Co.

Maas, Harro. 2014. "Making Things Technical: Samuelson at MIT." History of Political Economy 46 (supplement): 272-94.

Madra, Yahya, and Fikret Adaman. 2010. "Public Economics After Neoliberalism: A Theoretical-Historical Perspective." The European Journal of the History of Economic Thought 17 (4): 1079-1106.

Marciano, Alain. 2013. "Why Market Failures Are Not a Problem: James Buchanan on Market Imperfections, Voluntary Cooperation, and Externalities." History of Political Economy 45 (2): 223-54.

- - 2015. "Buchanan and Pro-Social Behaviors: Why Ethics is Necessary". CEconomia, 5(3), 295-311.

Marciano, Alain and Steven G. Medema. 2015. "Market Failure in Context: Introduction." History of Political Economy 47(S1): 1-19.

Mazzola, Ugo. 1890. "The formation of the prices of public goods" In Classics in the Theory of Public Finance, edited by Richard A. Musgrave and Alan T. Peacock, 37-47. London: Macmillan \& Co. Translated from "I Dati Scientific Della Finanza Pubblica".

Medema, Steven G. 2009. The Hesitant Hand: Taming Self-Interest in the History of Economic Ideas. Princeton: Princeton University Press.

- - 2012. "Textbooks as Data for the Study of the History of Economics: Lowly Beast or Fruitful Vineyard?" History of Economic Thought and Policy, (2): 193-207.

-_- 2015. "Exceptional and Unimportant'? The Rise, Fall, and Rebirth of Externalities in Economic Analysis." Working paper.

Minasian, Jora R. 1964. "Television Pricing and the Theory of Public Goods." Journal of Law and Economics 7: 71-80.

Musgrave, Peggy B. 2008. "Comments on Two Musgravian Concepts." Journal of Economics and Finance 32 (4): 340-47. 
Musgrave, Richard A. 1937. The Theory of Public Finance and the Concept of "Burden of Taxation". PhD Thesis. Harvard University.

- _ - 1939. "The Voluntary Exchange Theory of Public Economy." The Quarterly Journal of Economics 53 (2). Oxford University Press: 213-37.

- — 1941. "The Planning Approach in Public Economy : A Reply." The Quarterly Journal of Economics 55 (2): 319-24.

-_- 1945. "Fiscal Policy, Stability, and Full Employment." In Public Finance and Full Employment, 1-21. Washington: Board of Governors of the Federal Reserve System.

- - 1957a. "A Multiple Theory of Budget Determination." Finanzarchiv 17 (3): 333-43.

- - . 1957b. "Principles of Budget Determination." In Federal Expenditure Policy for Economic Growth and Stability. Papers Submitted by Panelists Appearing Before the Subcommittee on Fiscal Policy, 108-15. Washington DC: U.S. Congress.

Hill.

. 1959. The Theory of Public Finance: A Study in Public Economy. New York: McGraw

- - 1962. "The Public Interest: Efficiency in the Creation and Maintenance of Material Welfare." In NOMOS V The Public Interest, edited by Carl J. Friedrich, 107-14. New York: Prentice-Hall.

8.

-. 1964. "Efficiency Vs. Equity in Public Finance." Review of Social Economy 22 (1): 1-

- — . 1965. "Introduction." In Essays in Fiscal Federalism, edited by Richard A. Musgrave, 1-6. Washington DC: The Brookings Institution.

———. 1968. "Public Expenditures." In International Encyclopedia of the Social Sciences, edited by David L. Sill, 156-64. Crowell Collier and Macmillan.

- - . 1969a. "Provision for Social Goods." In Public Economics: An Analysis of Public Production and Consumption and Their Relations to the Private Sectors., edited by Julius Margolis and Henri Guitton. London: Macmillan.

- - 1 1969b. "Cost-Benefit Analysis and the Theory of Public Finance." Journal of Economic Literature 7(3): 797-806.

- - 1971. "Provision for Social Goods in the Market System." Public Finance = Finances Publiques 26 (2): 304-20.

- - . 1983. "Samuelson on Public Goods." In Paul Samuelson and Modern Economic Theory. Reprinted in Public Finance in a Democratic Society. Wheatsheaf Books. 1986.

- - - 1986. "In Retrospect." In Public Finance in a Democratic Society Volume I: Social Goods, Taxation, and Fiscal Policy. Wheatsheaf Books.

——_. 1989. “The Three Branches Revisited.” Atlantic Economic Journal 17 (1): 1-7. 
-_- 1992. "Social Science, Ethics, and the Role of the Public Sector." In Public Finance in a Democratic Society. Volume III, 104-15. Cheltenham: Edward Elgar. 2000.

-_- 1997. "Crossing Traditions.” In Zur Deutschsprachigen

Wirtschaftswissenschaftlichen Emigration Nach 1933, edited by H. Hagemann, 63-79. Marburg: Metropolis-Verlag. Reproduced in Public Finance in a Democratic Society. Volume III. 2000.

- _ 1999. "The Nature of the Fiscal State: The Roots of My Thinking." In Public Finance And Public Choice: Two Contrasting Visions of the State, edited by James M. Buchanan and Richard A. Musgrave, 29-49. Cambridge, MA: MIT Press/ CESifo.

Musgrave, Richard A., and Peggy B. Musgrave. 1973. Public Finance in Theory and Practice. First. New York: McGraw Hill.

Myrdal, Gunnar. 1930. The Political Element in the Development of Economic Theory. London: Routledge \& Kegan Paul Ltd. 1953. Translated from German Das Politische Element In Der Nationalökonomischen Doktrinbildung (1932) by Paul Streeten. Originally published in Swedish in 1930.

Neal, Alfred C. 1940. “The 'Planning Approach' in Public Economy.” The Quarterly Journal of Economics 54 (2). Oxford University Press: 246-254.

Nicholson, Walter and Christopher M. Snyder. 2011. Microeconomic Theory. Basic Principles and Extensions. Mason, OH: South-Western. Eleventh Edition.

Oates, Wallace E. 2007. "Remembering Richard Musgrave." Journal of Public Finance and Public Choice 25 (2-3): 97-02.

Olson, Mancur Jr. 1965. The Logic of Collective Action. Public Goods and The Theory of Groups. Cambridge, MA: Harvard University Press.

Ostrom, Vincent, and Elinor Ostrom. 1977. "Public Goods and Public Choices: The Emergence of Public Economies and Industry Structures." In E. S. Savas (ed.), Alternatives for Delivering Public Services: Toward Improved Performance, 7-49. Boulder, CO: Westview Press.

Ott, Attiat F, Robert M. Solow, Paul A. Samuelson, Henry J. Aaron, Martin S. Feldstein, and Oliver. Oldman. 2008. "A Tribute to Richard Abel Musgrave." Journal of Economics and Finance 32 (4): 330-33.

Peacock, Alan. 1953. "Sur La Théorie Des Dépenses Publiques." Économie appliquée: archives de l'Institut de science économique appliquée 6: 427-45.

- - 1954. "The Theory of the Public Economy." First Published in 2010 In The European Journal of the History of Economic Thought 17 (4): 559-77.

- - 1 1992. "The Demand for Historical Perspective." In Public Choice Analysis in Historical Perspective, edited by Diego Piacentino, 3-27. Cambridge: Cambridge University Press. 
Pickhardt, Michael. 2005. "Some Remarks on Self-Interest, the Historical Schools and the Evolution of the Theory of Public Goods." Journal of Economic Studies 32 (3): 275-93.

- - . 2006. "Fifty Years After Samuelson's 'Pure Theory of Public Expenditure' What Are We Left With?" Journal of the History of Economic Thought 28 (4): 439-60.

Pigou, A. C. 1928. A Study of Public Finance. London: Macmillan.

Samuelson, Paul A. 1947. Foundations of Economic Analysis. Cambridge, MA: Harvard University Press.

- - . 1954. "The Pure Theory of Public Expenditure." The Review of Economics and Statistics 36 (4): 387-89.

- - 1 1955. "Diagrammatic Exposition of a Theory of Public Expenditure." The Review of Economics and Statistics 37 (4): 350-56.

- - 1958. "Aspects of Public Expenditure Theories." The Review of Economics and Statistics 40 (4): 332-38.

- - . 1964. "Public Goods and Subscription TV: Correction of the Record." Journal of Law and Economics 7: 81-83.

- - 1969a. "Pure Theory of Public Expenditure and Taxation." In Public Economics: An Analysis of Public Production and Consumption and Their Relations to the Private Sectors., edited by Julius Margolis and Henri Guitton. London: Macmillan.

- - - 2008. "Affectionate Reminiscences of Richard Musgrave in Commemorating Richard Musgrave (1910-2007)." FinanzArchiv: Public Finance Analysis 64 (2): 145-70.

Sax, Emil. 1924. "The Valuation Theory of Taxation." In Classics in the Theory of Public Finance, edited by Richard A. Musgrave and Alan T. Peacock, 177-89. London: Macmillan \& Co.

Schlesinger, Arthur Jr., and Seymour E. Harris. 1957. "Introduction." In The New America by Adlai Stevenson, edited by Seymour E. Harris, John Bartlow Martin, and Arthur Jr. Schlesinger, xiii-xxx. New York: Harper \&Brothers.

Schumpeter, Joseph A. 1954. History of Economic Analysis. Routledge. 1986/2006 e-book edition.

Seidl, Christian. 1988. "Public Finance in a Democratic Society (Book Review)." Review of World Economics 124 (4): 775-84.

Seligman, Edwin Robert Anderson. 1908. Progressive Taxation in Theory and Practice. Publications of the American Economic Association (Princeton University Press). Second edition.

Singleton, John D. 2015. "Sorting Charles Tiebout". History of Political Economy 47(S1): 199226. 
Sinn, Hans-Werner. 2009. "Please Bring Me the New York Times: On the European Roots of Richard Abel Musgrave." International Tax and Public Finance 16 (1): 124-35.

Smith, Adam. 1776. An Inquiry into the Nature and Causes of the Wealth of Nations. The Glasgow Edition of the Works and Correspondence of Adam Smith. 1976. Indianapolis: Liberty Fund.

Solow, Robert M. 1997. "How Did Economics Get That Way and What Way Did It Get ?" Daedalus 126 (1): 39-58.

Sturn, Richard. 2006. "Subjectivism, Joint Consumption and the State: Public Goods in Staatswirtschaftslehre." The European Journal of the History of Economic Thought 13 (1): 39-67.

——_. 2010. "Public Goods' Before Samuelson: Interwar Finanzwissenschaft and Musgrave's Synthesis." The European Journal of the History of Economic Thought 17 (2): 279-312.

Tanzi, Vito. 2011. Government versus Markets. The Changing Economic Role of the State. New York: Cambridge University Press.

Tiebout, Charles M. 1956. "A Pure Theory of Local Expenditures.” The Journal of Political Economy 64 (5). 416-24.

Tuck, Richard. 2008. Free Riding. Cambridge, MA: Harvard University Press.

Varian, Hal R. 1992. Microeconomic Analysis. Third edition. Norton.

Ver Eecke, Wilfried. 1999. "Public Goods: An Ideal Concept.” Journal of Socio-Economics 28 (2): $139-56$.

Wagner, Adolf. 1883. "Finanzwissenshaft." In Classics in the Theory of Public Finance, edited by Richard A. Musgrave and Alan T. Peacock, 1-15. London: Macmillan \& Co.

- - 1892. Grundlegung Der Politischen Oekonomie. French Translation of the third German edition. Les fondements de l'économie politique. 1904. Paris: V. Giard et E. Brière.

Wicksell, Knut. 1896. "A New Principle of Just Taxation.” In Classics in the Theory of Public Finance, edited by Richard A. Musgrave and Alan T. Peacock, 72-118. London: Macmillan \& Co. 